\title{
Evaluation of the Ground-Water Contaminant Plume Extending from the 183-H Solar \\ Evaporation Basins
}

S. H. Hall

October 1989

Prepared for the U.S. Department of Energy under Contract DE-AC06-76RLO 1830

Pacific Northwest Laboratory

Operated for the U.S. Department of Energy by Battelle Memorial Institute 


\title{
DISCLAIMER
}

This program was prepared as an account of work sponsored by an agency of the United States Government. Neither the United States Government nor any agency thereof, nor Battelle Memorial Institute, nor any or their employees, makes any warranty, expressed or implied, or assumes any legal liability or responsibility for the accuracy, completeness, or usefulness of any information, apparatus, product, or process disclosed, or represents that its use would not infringe privately owned rights. Reference herein to any specific commercial product, process, or service by trade name, trademark, manufacturer, or otherwise, does not necessarily constitute or imply its endorsement, recommendation, or favoring by the United States Government of any agency thereof, or Battelle Memorial institute. The views and opinions of authors expressed herein do not necessarily state or reflect those of the United States Government or any agency thereof.

\author{
PACIFIC NORTHWEST LABORATORY \\ operated by \\ BATTELLE MEMORIAL INSTITUTE \\ for the \\ UNITED STATES DEPARTMENT OF ENERGY \\ under Contract DE-ACO6-76RLO 1830
}

Printed in the United States of America

Available to DOE and DOE contractors from the

Office of Scientific and Technical Information, P.O. Box 62, Oak Ridge, TN 37831; prices available from (615) 576-8401. FTS 626-8401.

Available to the public from the National Technical Information Service,

U.S. Department of Commerce, 5285 Port Royal Rd., Springfield, VA 22161.

NTIS Price Codes, Microfiche A01

Printed Copy

\begin{tabular}{|c|c|}
\hline Pages & $\begin{array}{l}\text { Price } \\
\text { Codes }\end{array}$ \\
\hline $001-025$ & $\mathrm{A02}$ \\
\hline $026-050$ & $\mathrm{~A} 03$ \\
\hline $051-075$ & $\mathrm{AOS}$ \\
\hline $076-100$ & A05 \\
\hline $101-125$ & $A 06$ \\
\hline $126-150$ & $\mathrm{~A} 07$ \\
\hline $151-175$ & $A 08$ \\
\hline $176-200$ & $A 09$ \\
\hline $201-225$ & A10 \\
\hline $226-250$ & A11 \\
\hline $251-275$ & A12 \\
\hline $276-300$ & A13 \\
\hline
\end{tabular}


PNL-7130

UC-903

EVALUATION OF THE GROUND-WATER

CONTAMINANT PLUME EXTENDING FROM

THE I83-H SOLAR EVAPORATION BASINS

S. H. Hall

October 1989

Prepared for

the U.S. Department of Energy

under Contract DE-ACO6-76RLO 1830

Pacific Northwest Laboratory

Richland, Washington 99352 


\section{$\underline{\text { SUMMARY }}$}

The 183-H Solar Evaporation Basins, located on the Hanford Site in southeastern Washington State, were used for solar concentration and storage of process wastes that consisted of nitric, sulfuric, and hydrofluoric acids, contaminated by heavy metals and radionuclides, and neutralized by sodium hydroxide. By 1977, it was apparent that leakage from the basins had reached the unconfined aquifer, causing elevated ground-water concentrations of nitrate, chromium, technetium-99, and uranium. The resulting plume is superimposed on a larger, pre-existing plume from upgradient sources that is characterized by the same contaminants, but with different relative concentrations. The plumes discharge into the Columbia River, $210 \mathrm{~m}$ from the basins.

This study examines the relative concentration ratios of the contaminants, determines which wells in the monitoring network surrounding the basins have been affected by basin leakage, assigns reasonable plume boundaries, and shows the separate contribution of each plume to ground-water contamination downgradient from the basins.

A pulse of nitrate contamination in the ground water, possibly caused by decontamination activities at the basins, was used to establish a groundwater flow rate of 49 to $64 \mathrm{~cm} / \mathrm{d}$ between the basins and the river. Plume dimensions and integration of historical nitrate concentrations were used to estimate that roughly $200,000 \mathrm{~L}$ of the $3.6 \mathrm{M}$ sodium nitrate solution has leaked from the basins, migrated through unsaturated sediments beneath the basins, and reached the water table. A worst-case analysis suggests that a comparable volume of waste liquid may have been retained in the vadose zone by capillarity. Of the waste liquid that reached the water table, most has been transported and discharged to the river. 


\section{CONTENTS}

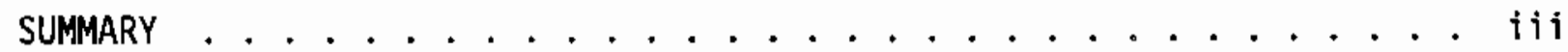

INTRODUCTION . . . . . . . . . . . . . . . . . . . . 1

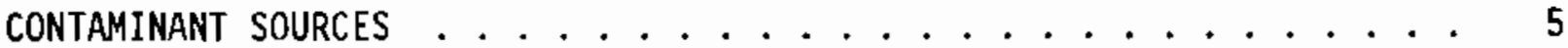

WELLS AFFECTED BY THE BASIN PLUME . . . . . . . . . . . . . . . 6

PLUME BOUNDARIES ........................ 10

MIGRATION RATE . . . . . . . . . . . . . . . . . . . . . 13

ESTIMATE OF TOTAL CONTAMINANT FLUX $\ldots . . . . . . . . . . .15$

DISCUSSION . . . . . . . . . . . . . . . . . . . . 18

CONCLUSIONS . . . . . . . . . . . . . . . . . . . . . 23

REFERENCES ........................... 25 


\section{FIGURES}

1 Location of the Hanford Site and the 183-H Solar Evaporation Basins ................... 1

2 The 100-H Area and the 183-H Solar Evaporation Basins ....... 2

3 Nitrate Versus Chromium Concentration for Ground-Water Samples Collected from the $100-\mathrm{H}$ Area . . . . . . . . . . . 9

4 Relative Concentration of Chromium, Uranium, and Technetium-99 in Ground-Water Samples Collected from the 100-H Area from August 1987 to September $1988 \ldots \ldots . \ldots 11$

5 Piper Diagram Showing the Major Ion Chemistry for Ground-Water Samples Collected from the 100-H Area during September 1988 . . . . 12

6 Nitrate Concentration in Ground-Water Samples from

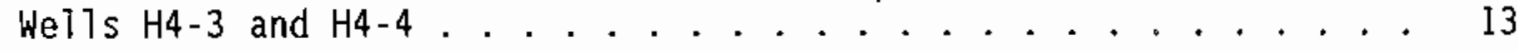

7 Concentration Profile Across the width of the Contaminant Plume Near the Columbia River. . . . . . . . . . . . . 16

8 Composition of Basin \#1 Liquid Compared to the Composition of the Ground-Water Contaminant Plume . . . . . . . . . . 20

\section{$\underline{\text { TABLES }}$}

1 Analysis of Liquid Waste from Two of the 183-H Solar Evaporation Basins. . . . . . . . . . . . . 5

2 Mean and Range of Chemical Analys is of Ground-Water Samples from Wells Near the 183-H Solar Evaporation Basins, July 1987 to September 1988

3 Correlation of Nitrate Concentrations of Wells $\mathrm{H} 4-3$ and $\mathrm{H} 4-4$, Assuming 8 Months Travel Time from Well H4-3 to Well H4-4, and a $19 \mathrm{mg} / \mathrm{L}$ Background Concentration

4 Total Nitrate Flux from Basin \#1, Based on Estimated Plume Dimensions at Well H4-4, Flow Rate, and Concentration Data from We $11 \mathrm{H} 4-3$ 


\section{INTROOUCTION}

From 1973 to 1985, the 183-H Solar Evaporation Basins, which are four contiguous concrete basins in the 100- $\mathrm{H}$ Area at the Hanford Site, Washington (Figures 1 and 2), were used for solar evaporation and storage of aqueous chemical wastes from nuclear fuel processing operations elsewhere on the Site. Basin leakage has caused local ground-water contamination in the unconfined aquifer. The contaminant plumes and basins have been the subject of a Resource Conservation and Recovery Act (RCRA) ground-water monitoring and hydrogeologic characterization project since June 1985. This study, sponsored by Westinghouse Hanford Company and carried out by Pacific Northwest Laboratory(a), is an attempt to resolve the plume against a background of similar contamination from upgradient sources.

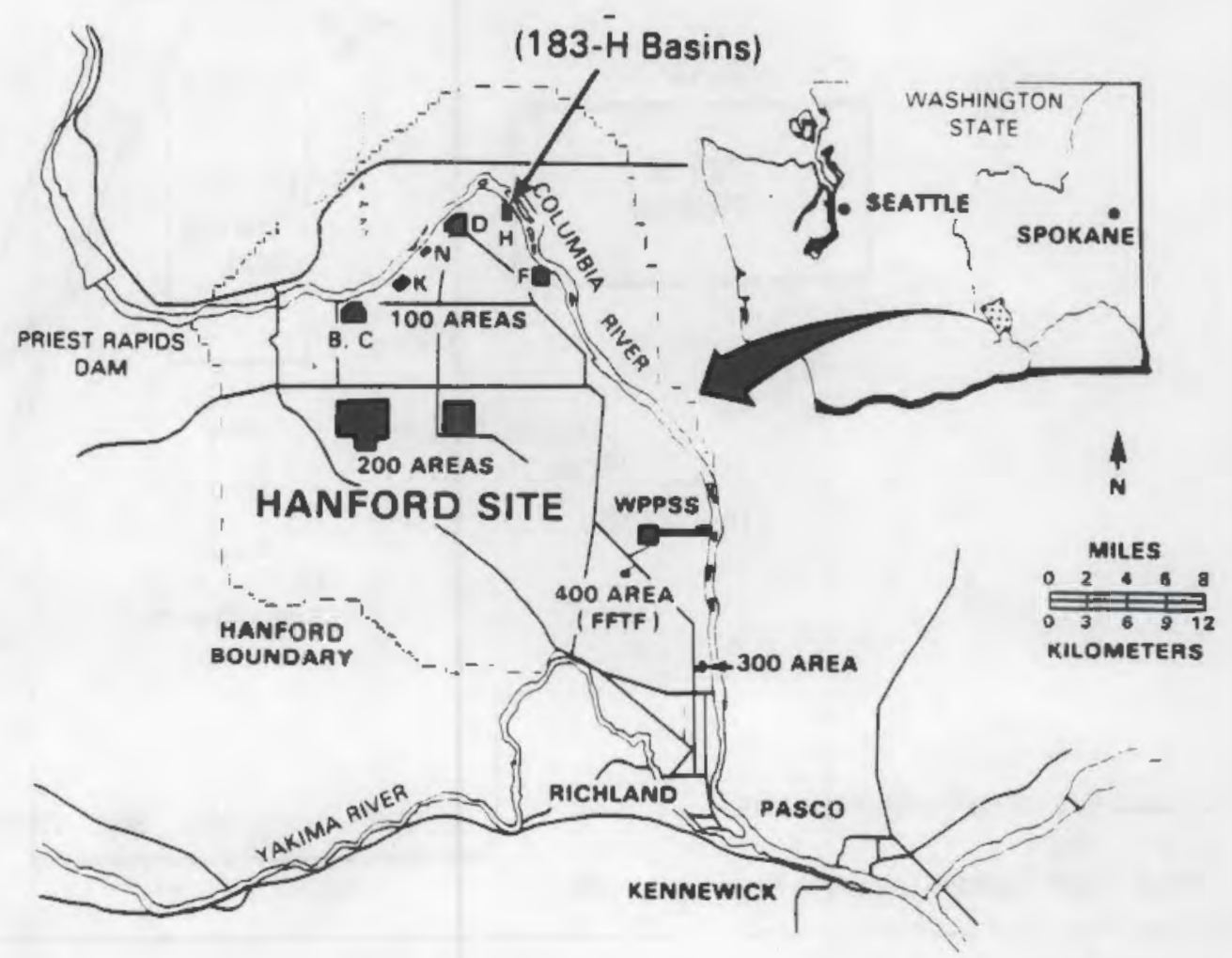

FIGURE 1. Location of the Hanford Site and the 183-H Solar Evaporation Basins

(a) Pacific Northwest Laboratory is operated for the U.S. Department of Energy by Battelle Memorial Institute under Contract DE-AC06-76RLO 1830 


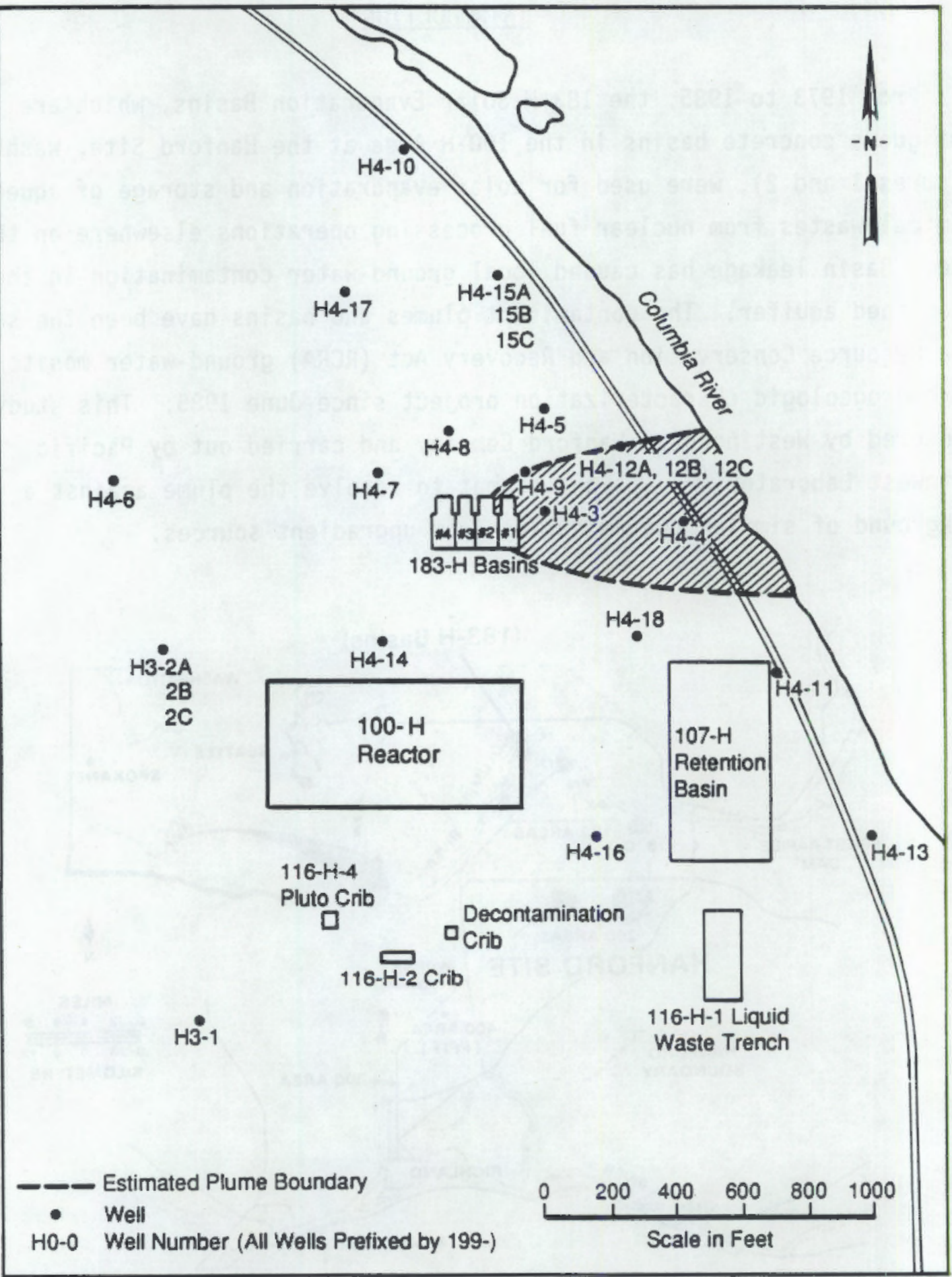

FIGURE 2. The 100-H Area and the 183-H Solar Evaporation Basins 
Originally, the four basins, each having a capacity of $1,700,000 \mathrm{~L}$, were used as flocculating and settling basins for the water treatment plant that served the 100-H plutonium production reactor (Greager 1982). During the production life of the reactor, the basins would not have contained hazardous materials. Between 1965, when the reactor was retired, and 1973, the basins were unused. In June 1973, 30,000 L of mixed wastes from the 300 Area fue 1 fabrication facilities were discharged to basin \#1. No waste was discharged to the basin in 1974, but from January 1975 until August 1978, it received waste at the rate of about $550,000 \mathrm{~L} / \mathrm{yr}$.

The wastes discharged to the basins consisted primarily of nitric, sulfuric, and hydrofluoric acids, contaminated by heavy metals and radionuclides, and neutralized by sodium hydroxide (Greager 1982; Liikala et a1. 1988). Elevated nitrate concentrations were apparent in water samples collected from well H4-3 by mid-1977, indicating that the basin was leaking. Basins \#2 and \#3 were coated with urethane prior to receiving wastes, and were ready for service by August 1978. At that time, the waste stream was redirected to basins $\# 2$ and $\# 3$, and the liquid fraction of the waste remaining in basin \#I was pumped to the newly prepared basins, leaving a slurry in basin \#1. The slurry was removed from the basin in July 1985 . There is no evidence of leakage from basin \#2 or \#3 (or from basin \#4, later put into service after lining with a butyl and Hypalon ${ }^{\mathrm{m}(\mathrm{a})}$ coating).

Leakage from basin \#l resulted in a contaminant plume in the unconfined aquifer (Liikala et al. 1988) that extends from the basin to the Columbia River. During 1988, contaminants whose ground-water concentrations were found to exceed drinking water standards (Fruland and Lundgren 1989) are nitrate, chromium, and technetium-99 (the standards are $45 \mathrm{mg} / \mathrm{L}, 50 \mu \mathrm{g} / \mathrm{L}$, and $900 \mathrm{pCi} / \mathrm{L}$, respectively). Elevated uranium concentrations are also found in the plume. This plume has been superimposed on a preexisting, and much larger, plume that was caused by the coalescence of plumes extending from at least four known liquid waste disposal sites in the vicinity of the $100-\mathrm{H}$ reactor (Stenner et al. 1988). This larger plume (the "reactor plume") exists today principally as chromium contamination from the disposal of an

(a) Hypalon is a registered tradename of the E. I. du Pont de Nemours Co., Wilmington, Delaware. 
estimated $3,700 \mathrm{~kg}$ of sodium dichromate in wastewater from reactor operations to the soil column, and hence to the unconfined aquifer, from 1950 to 1965.

Differentiating the plume from solar evaporation basin \#1 (the "basin plume") from the reactor plume is complicated by the proximity of the Columbia River. First, the plumes are truncated by the river, so the rate of migration cannot be estimated by monitoring the movement of the plume front through the aquifer. Second, although net annual flow is toward the river, seasonal variations in river stage cause temporary reversals of the hydraulic gradient in the unconfined aquifer near the river at the 100-H Area.

All of the contaminants noted above as characteristic of the basin plume are also found in the reactor plume (PNL 1987a, 1987b; PNL 1988a, 1988b; Fruland et a1. 1989a, 1989b). However, the relative concentrations of the contaminants are quite different for each plume.

This report presents geochemical and related evidence to del ineate the basin plume, and to differentiate it from the reactor plume. When this has been established, the basin plume boundaries are estimated within the limits of accuracy imposed by the density of monitoring well locations. Next, the plume's net migration rate toward the river is estimated. Finally, a coarse estimate of the total discharge of contaminants from basin \#1 is provided.

One purpose served by such estimates is to provide a basis for the examination and evaluation of engineering options for site reclamation. Another is to provide information useful in coordinating the ongoing RCRA investigation with a recently begun Comprehensive Environmental Response, Compensation, and Liability Act (CERCLA) investigation whose focus includes the sources of the reactor plume. 


\section{CONTAMINANT SOURCES}

Table 1 shows the mean chemical analysis of the liquid fraction of slurry samples collected from basin \#1 in October 1984, and the analysis of the supernatant liquid samples collected from basin \#2 in November 1986 (Liikala et a1. 1988). Apparently, the slurry from basin \#1 was trapped between solid crystalline layers, which prevented complete dehydration during the 6 years following removal of the supernatant liquid waste from that basin. All waste shipment to the basins was halted in November 1985, so the liquid from basin \#2 would have been subject to solar evaporation for at least 1 year. The data in Table 1 show a remarkable similarity in sodium nitrate content between the basin \#1 slurry liquid and the basin \#2 supernatant liquid. That similarity is interpreted here as evidence that major chemical components of both liquids are approximately at saturation for evaporation of this waste stream (pure sodium nitrate would be expected to exhibit significantly greater solubility).

TABLE 1. Analysis of Liquid Waste from Two of the 183-H Solar Evaporation Basins. Units are in $\mathrm{mg} / \mathrm{L}$, except $\mathrm{pH}$ or as noted. (Data from Liikala et al. 1988)

\begin{tabular}{|c|c|c|}
\hline \multirow[b]{2}{*}{ Constituents } & \multicolumn{2}{|c|}{ Sampling Date/Location } \\
\hline & $\begin{array}{l}\text { October 1984, } \\
\text { Basin \#1 (a) }\end{array}$ & $\begin{array}{c}\text { November 1986/ } \\
\text { Basin \#2 } \\
\end{array}$ \\
\hline $\begin{array}{l}\mathrm{CO}_{3} \\
\mathrm{HCO} \\
\mathrm{pH} \\
\mathrm{Na} \\
\mathrm{NO}_{3} \\
\mathrm{SO}_{4} \\
\mathrm{Cr} \\
\mathrm{K} \\
\mathrm{S} \\
\mathrm{U} \\
\mathrm{F} \\
\mathrm{Cl} \\
\mathrm{Cu} \\
\mathrm{Nj} \\
{ }_{9} \mathrm{Tc} \quad(\mathrm{pCi} / \mathrm{L})\end{array}$ & $\begin{array}{c}2290 \\
4950 \\
9.55 \\
107,000 \\
220,000 \\
23,000 \\
64 \\
750 \\
8120 \\
653 \\
3900 \\
700 \\
360 \\
17 \\
7.5 \times 10^{5}\end{array}$ & $\begin{array}{c}10.5 \\
113,000 \\
260,000 \\
8,900 \\
8.3 \\
160\end{array}$ \\
\hline
\end{tabular}

(a) Mean results for five samples. 
Liikala et al. report that the basin contents were stratified during service life, that is, the crystalline products of evaporation covered the bottoms of the basins as a dense slurry, and were in turn covered by the supernatant liquid wastes. The supernatant liquid was at least partially covered by a crystalline crust. The abundance of crystalline material suggests that liquid escaping from a basin would have been at or near saturation. Basin \#1 is known to have leaked, so the composition of the liquid fraction of slurry samples collected from that basin is considered here to be probably representative of the waste liquid that escaped from the basin, migrated downward through the soil column, and reached the water table to become the source of the basin plume. For this discussion, geochemical reactions such as sorption, precipitation, or ion exchange that may occur between the vadose zone sediments and the waste liquid will be disregarded.

Historical information regarding the sources of the reactor plume is meager, at best, but the effects of the plume's composition on the ground water beneath the basins can be seen by inspecting chemical data for samples collected from monitoring well $\mathrm{H4-14}$, which is within the reactor plume, but upgradient from the solar evaporation basins. Table 2 summarizes chemical data for well H4-14 for the period July 1987 to September 1988 (PNL 1987a, 1987b, 1988a, 1988b; Fruland et al. 1989a). Data for well H4-3, immediately downgradient from the basins, are included for comparison. Comparison of Table 1 and Table 2 shows that the basins are the source of elevated nitrate, sodium, uranium, and technetium-99 in well H4-3. The source for chromium, however, is not clear.

\section{WELLS AFFECTED BY THE BASIN PLUME}

By examining relative concentration ratios of the contaminants in ground-water samples, it is possible to determine which wells in the monitoring network have been affected by basin leakage.

The relative volumes of the upgradient source (the reactor plume) and the basin leakage source that comingled beneath basin \#1 must be considered. Greager (1982) reports that the maximum nitrate concentration in well $\mathrm{H4-3}$, $8000 \mathrm{mg} / \mathrm{L}$, occurred in July 1978. Simple mixing calculations based on that peak concentration and on the probable concentration of the basin source 
TABLE 2. Mean and Range of Chemical Analysis of Ground-Water Samples from Wells Near the 183-H Solar Evaporation Basins, July 1987 to September 1988. Units are in $\mathrm{mg} / \mathrm{L}$, except as noted. (Data from PNL 1987a, 1987b, 1988a, 1988b; Fruland et a1. 1989a, 1989b).

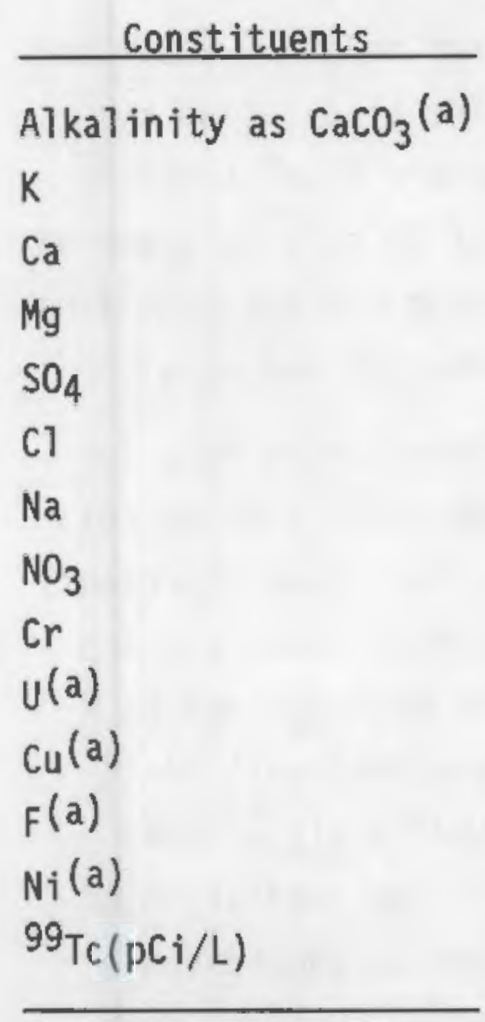

\begin{tabular}{|c|c|c|c|}
\hline \multicolumn{2}{|c|}{ H4-3 (downgradient) } & \multicolumn{2}{|c|}{ H4-14 (upgradient) } \\
\hline Mean & Range & Mean & Range \\
\hline 152 & $151-153$ & 100 & $99-102$ \\
\hline 5.1 & $3.5-7.9$ & 4.1 & $3.8-4.4$ \\
\hline 25 & $12-54$ & 42 & $34-49$ \\
\hline 4.5 & $2.0-9.3$ & 8.1 & $7.7-8.9$ \\
\hline 95 & $78-129$ & 40 & $37-43$ \\
\hline 9.6 & $8.0-10.8$ & 5.2 & $4.8-5.5$ \\
\hline 243 & $168-450$ & 7.6 & $7.3-8.5$ \\
\hline 407 & $170-1020$ & 19 & $17-21$ \\
\hline 0.256 & $0.194-0.397$ & 0.348 & $0.270-0.0025$ \\
\hline 0.140 & $0.084-0.237$ & 0.0022 & $0.0020-0.474$ \\
\hline 0.021 & $<0.010-0.049$ & $<0.010$ & \\
\hline 0.8 & $<0.5-1.4$ & $<0.5$ & \\
\hline 0.023 & $0.010-0.043$ & $<0.010$ & \\
\hline 460 & $1320-4430$ & 2 & $<1-3$ \\
\hline
\end{tabular}
(a) Analytical data representing the entire July 1987 - September 1988
period are not available.

(Table 1) show that the basin source contribution would have been less than 4 vol\%. For the purposes of this study, this small volume correction can be ignored. Further, it has been over a decade since the liquid waste, and thus, the hydraulic driving force for leakage, was removed from basin \#1. Therefore, it is reasonable to treat the total leakage as a slug of soluble saits that was introduced to the ground water, and that had a fixed and characteristic ratio of nitrate to chromium. It is assumed that both the nitrate and chromium are conservative within the ground-water regime. [Chromium in basin \#I was in the hexavalent form according to Liikala et al. (1988). Sodium dichromate, in which the chromium is also hexavalent, is the source material for the reactor plume.] 
If the nitrate and chromium from basin \#1 had been introduced to ground water that was devoid of these ions, a plot of nitrate versus chromium for any water sample affected by the resulting plume would lie along a straight line the slope of which is equal to the nitrate to chromium ratio of the original slug of salts, and which passes through the plot origin. Position of points along that line would depend only on the degree of dilution by ground water. Where upgradient ground water has measurable concentrations of nitrate and chromium (e.g., the nitrate background of $19 \mathrm{mg} / \mathrm{L}$ as shown in Table 2), axial intercepts are introduced to the plot, and the straight line will no longer pass through the origin, unless the intercepts are equal.

Figure 3 is such a plot for chemical ground-water monitoring data for seven wells in the vicinity of the basins. The data represent samples collected from July 1987 to September 1988. Line a has a slope that represents the nitrate to chromium ratio of the basin \#1 slurry liquid (Table 1), and it has an intercept on the nitrate axis that represents the mean nitrate background of the ground water, $19 \mathrm{mg} / \mathrm{L}$, represented in upgradient well H4-14. Thus, the line represents the plot that would be expected if all of the chromium in the ground water were due to basin leakage. The population of data points in the area labeled $\underline{b}$ represents samples showing considerable chromium contamination, but whose nitrate concentrations do not rise much above background levels. The chromium contamination found in these wells (H4-14 and H4-18) must be due to the reactor plume, and not basin $\# 1$.

The population of data in the area labeled $\underline{c}$ clearly forms a lobe that is approximately parallel to line a, but shifted to the right. The amount of lateral shift represents an axial translation caused by chromium contamination from the reactor plume. Lobe $\underline{c}$ includes data from wells $\mathrm{H} 4-3$ and H4-4, both of which are directly downgradient from the basins. By extrapolating we11 H4-3 data in lobe $\underline{c}$ to the chromium concentration axis, an intercept of about $0.140 \mathrm{mg} / \mathrm{L}$ is obtained. The sum of this concentration and the $0.010 \mathrm{mg} / \mathrm{L}$ represented by the short $\mathrm{x}$-axis component shown as $\underline{\mathrm{e}}$ is the mean chromium background concentration for the period, or about $0.150 \mathrm{mg} / \mathrm{L}$. In other words, during the period of time represented by the data in the figure, an average of $0.150 \mathrm{mg} / \mathrm{L}$ of the chromium contamination found in samples from well H4-3 was from the reactor plume, and the balance was from basin leakage. 


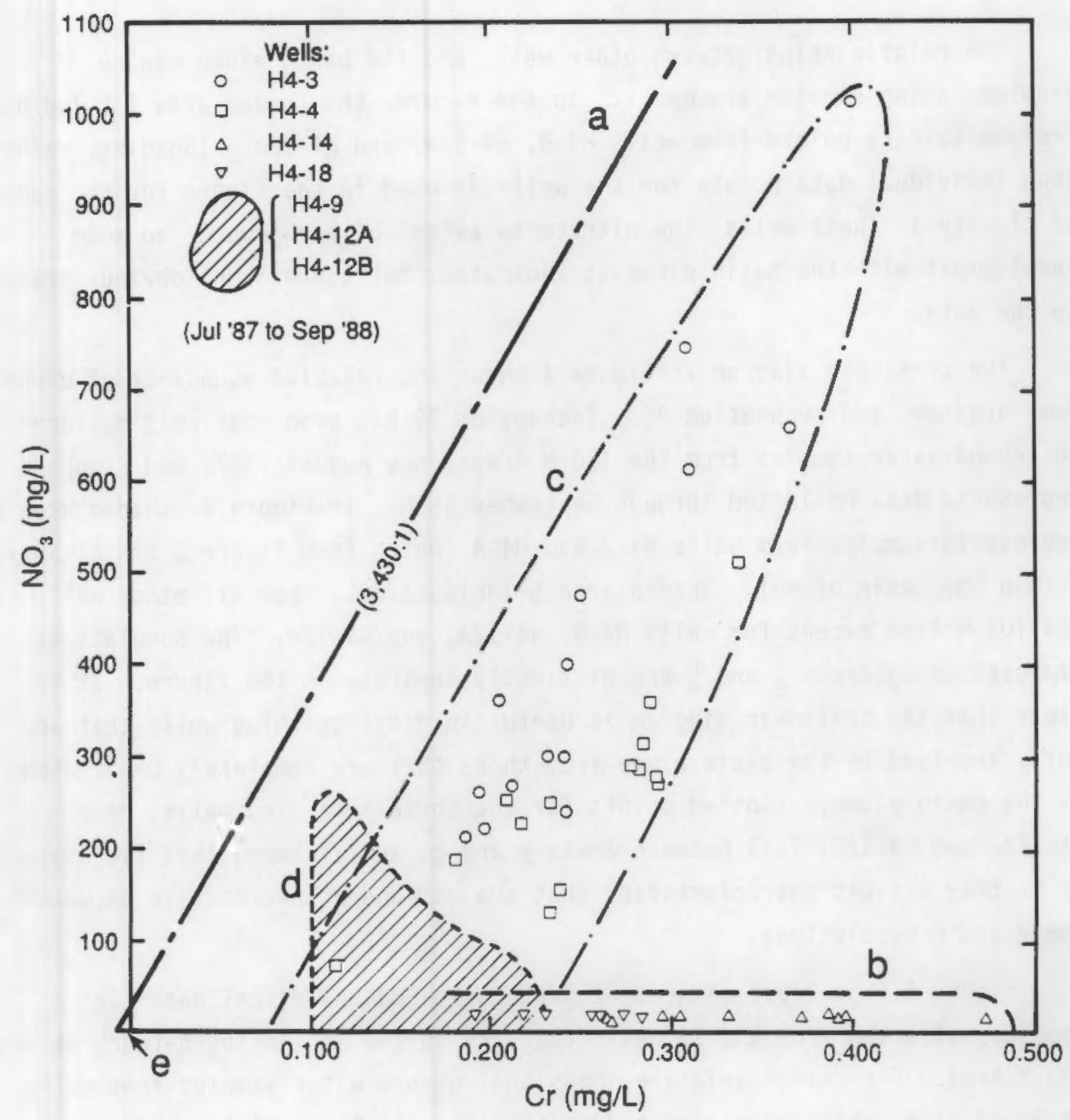

FIGURE 3. Nitrate Versus Chromium Concentration for Ground-Water Samples Collected from the $100-\mathrm{H}$ Area

The data for well H4-4 yield a similar value. Much of the scatter in the data is due to considerable temporal variation of the chromium concentration of the reactor plume. Lobe $c$ provides conclusive evidence that wells $\mathrm{H} 4-3$ and H4-4 intercept the basin plume. Lobe b shows that well H4-18, like upgradient well H4-14, is unaffected by the basin plume. 
The relationships between other wells and the basin plume can be examined using similar arguments. In the figure, the shaded area labeled $\underline{d}$ represents data points from wells H4-9, H4-12A, and H4-12B. (Shading, rather than individual data points for the wells is used in the figure for the sake of clarity.) These wells show nitrate in excess of background, so some involvement with the basin plume is indicated, but there is no obvious trend to the data.

The trilinear diagram in Figure 4 shows the relative abundance of chromium, uranium, and technetium-99. Technetium-99 has been routinely measured in ground-water samples from the 100-H Area since August 1987, and Figure 4 represents data collected through September 1988. In Figure 4, shaded area a represents samples from wells $\mathrm{H} 4-3$ and $\mathrm{H4-4}$ (which from Figure 3 are clearly within the basin plume). Shaded area $\underline{b}$ includes data from all other wells in the 100-H Area except for wells $\mathrm{H} 4-9, \mathrm{H} 4-12 \mathrm{~A}$, and H4-12B. The populations represented by areas $\underline{a}$ and $\underline{b}$ are distinctly separate in the figure. It is clear that the trilinear diagram is useful in distinguishing wells that are fully involved by the basin plume from those that are completely unaffected by the basin plume. Plotted points for the three remaining wells, H4-9, $\mathrm{H} 4-12 \mathrm{~A}$, and $\mathrm{H} 4-12 \mathrm{~B}$, fall between areas $\underline{\mathrm{a}}$ and $\underline{\mathrm{b}}$, and $\mathrm{a} 1$ though they 1 ie closer

to $\underline{a}$, they exhibit characteristics that are somewhere intermediate between the $\underline{a}$ and $\underline{b}$ populations.

Figure 5 is a Piper diagram of September 1988 analytical data for samples collected from all 23 wells that are in the monitoring network at the 100-H Area. The cation triangle shows that ground-water samples from wells H4-3 and H4-4, which have elevated sodium concentrations caused by contamination from the basins, are chemically different than samples from the other wells, while samples from $\mathrm{H} 4-9, \mathrm{H} 4-12 \mathrm{~A}$, and $\mathrm{H} 4-12 \mathrm{~B}$ are indistinguishable from those of the other wells.

\section{PLUME BOUNDARIES}

Figures 3 through 5 show that wells $\mathrm{H} 4-9, \mathrm{H} 4-12 \mathrm{~A}$, and $\mathrm{H} 4-12 \mathrm{~B}$ are affected by the basin plume, but only slightly. This can be true only if these wells lie along the plume's margin. Thus, as shown in Figure 2, these wells can be used to define an entirely reasonable northern plume boundary. 


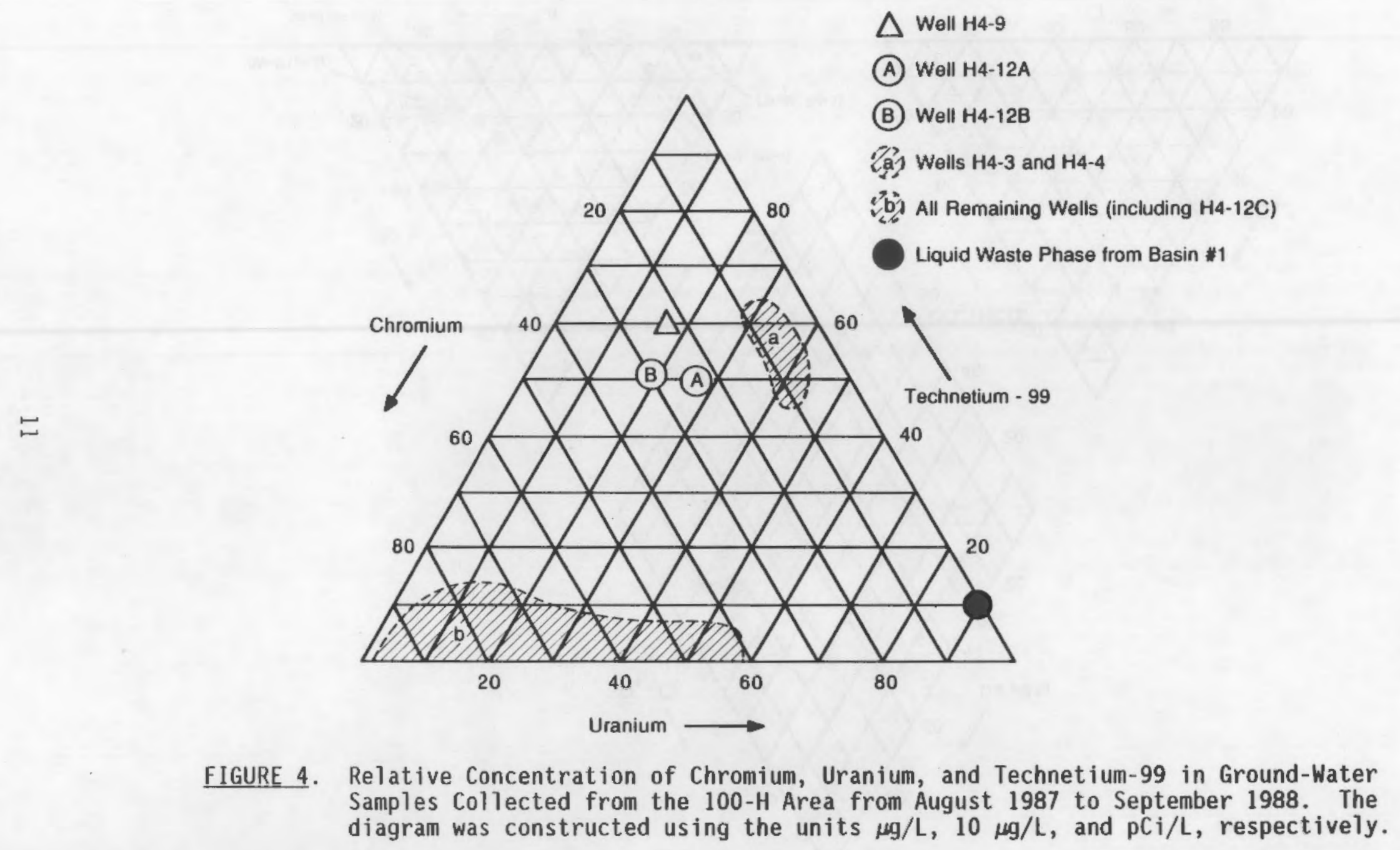




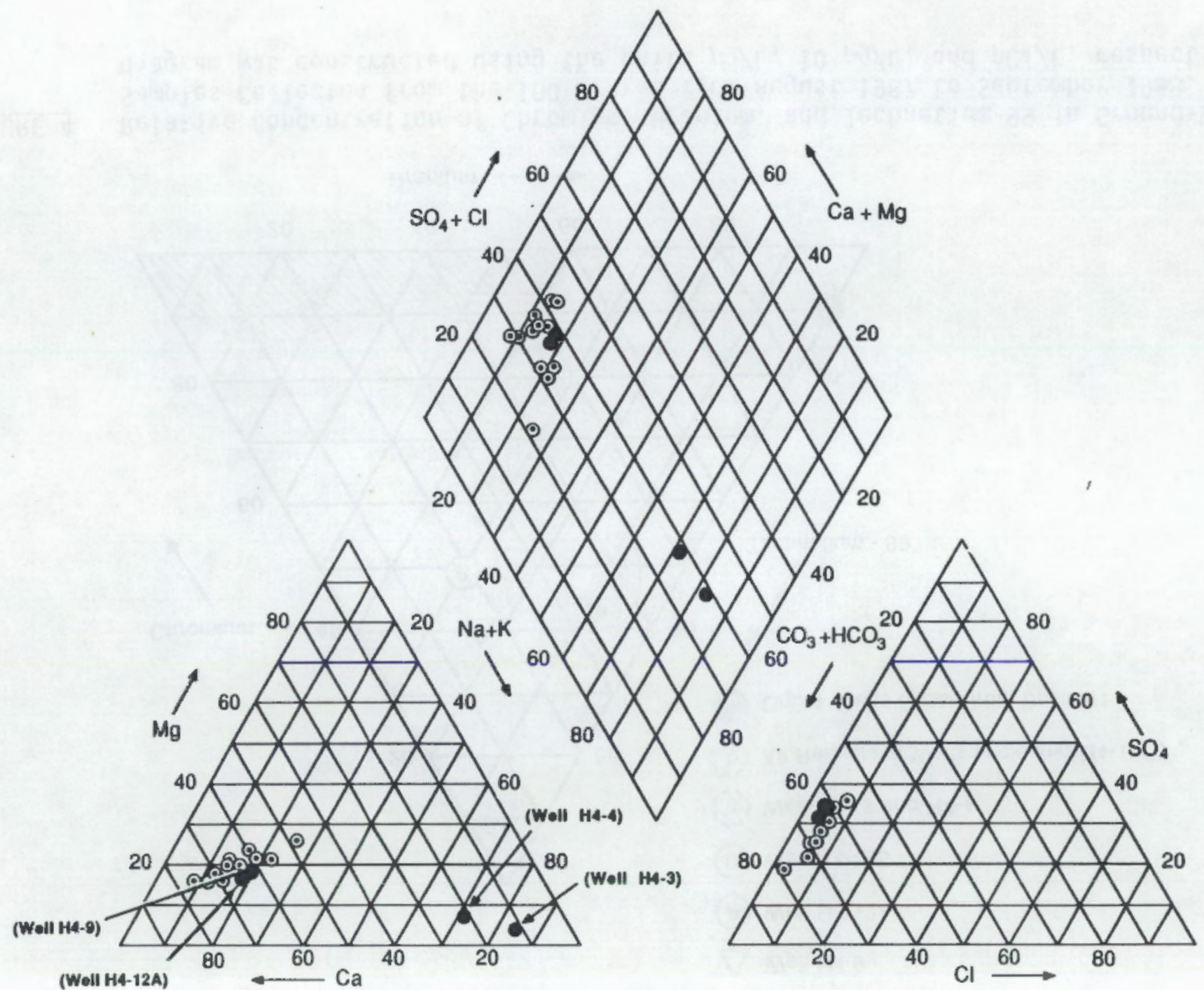

FIGURE 5. Piper Diagram Showing the Major Ion Chemistry for Ground-Water Samples Collected from the 100-H Area during September 1988 
The southern boundary of the basin plume must lie along a path extending from the basins, eastward to the river, and somewhere between wells $\mathrm{H4-4}$ and H4-18. The existing monitoring well network, and the resulting geochemical data, do not fix the location of the southern boundary in the manner that the northern boundary is fixed.

\section{MIGRATION RATE}

Figure 6 shows nitrate concentration as a function of time for wells H4-3 and H4-4. Both graphs in the figure show significant seasonal variation associated with river stage fluctuations. On January 22, 1986, an increase in nitrate concentration was detected in a sample collected from well H4-3. Inspection of the figure shows that this pulse of nitrate is too large to be attributed to seasonal fluctuation, and must therefore represent additional
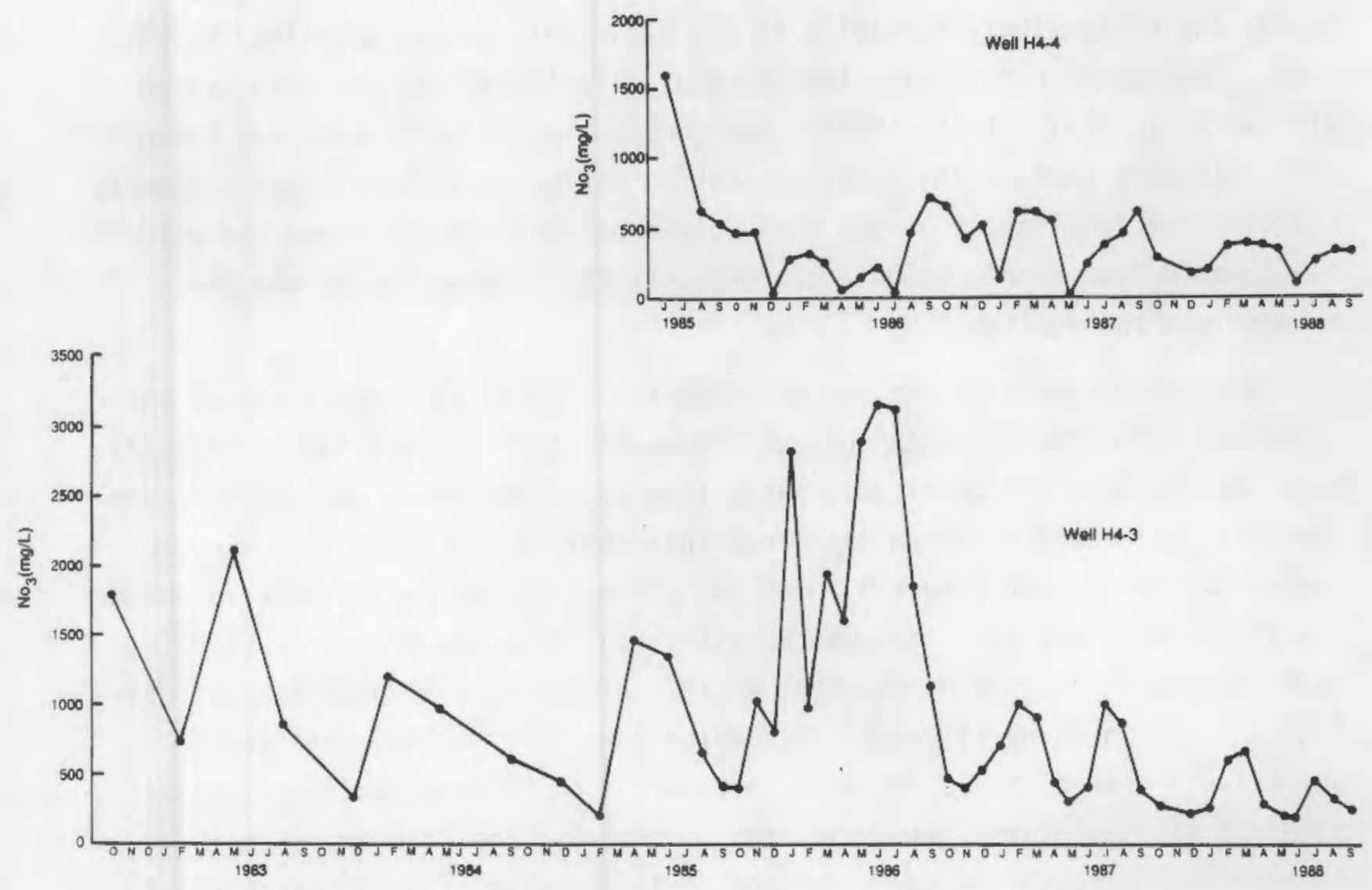

FIGURE 6. Nitrate Concentration in Ground-Water Samples from Wells H4-3 and H4-4 
nitrate added to the ground water. The well had been previously sampled on December 13, 1985, so arrival of the pulse at well H4-3 occurred sometime between these two dates. Similarly, the nitrate pulse was detected downgradient in well H4-4 on September 15, 1986. (The previous sample from well H4-4 was collected on August 20, 1986.) No such pulse was detected in upgradient wells, so the additional nitrate must have come from the basins.

The nitrate pulse, seen first at well H4-3 and later at well H4-4 provides a convenient chemical marker that can be used to calculate net plume migration rate. Based on the $133-\mathrm{m}$ distance between the wells, that rate is calculated to be 49 to $64 \mathrm{~cm} / \mathrm{d}$. This is somewhat faster than the $21 \mathrm{~cm} / \mathrm{d}$ net plume migration rate that Liikala et al. (1988) estimated using a computer ground-water flow modeling technique.

The additional nitrate detected in both wells may have been an inadvertent result of the effort to empty and decontaminate basin \#1. As noted above, the waste slurry remaining in the basin was removed starting in July 1985. Subsequent decontamination procedures included high-pressure hosing with water (Liikala et al. 1988). Any combination of wash water and meteoric water escaping through the original leak in the basin in sufficient volume to overcome the capillarity of the soil column between the basin and the water table could have washed soluble contaminants still remaining on the soil column into the aquifer.

Another explanation for the occurrence of the pulse is that one of the remaining three basins began to leak. However, that explanation is rejected here because data for the liquid phase from basin $\# 2$ show a nitrate to chromium ratio of $31,325: 1$, quite different than that of the basin \#1 slurry 1 iquid $(3,438: 1)$, and Figure 3 shows quite clearly that the nitrate to chromium ratio in ground water for wastes attributable to the basins in recent years is characteristic of basin \#l waste. Although it is possible that the liquid in basin \#3 or \#4 closely resembles that of basin \#1, this seems unlikely in view of the difference in composition between basins $\# 1$ and \#2. Finally, it is possible, although highly unlikely, that the increase in chromium and nitrate are due to ground spillage associated with removal of the slurry from the basin. 


\section{ESTIMATE OF TOTAL CONTAMINANT FLUX}

Knowing the location of the plume boundaries, and therefore the width of the basin plume as it enters the river, is important for estimating the flux of contaminants into the river for any given ground-water flow rate. It is also important to know the peak concentration of the plume and to estimate how concentration decreases with distance from the plume axis. A concentration profile perpendicular to the plume axis can be treated as a simple triangular distribution. Such a model is assumed here and is illustrated in Figure 7.

If well H4-4 is assumed to lie on the plume axis, then the concentrations measured in samples from that well represent peak plume concentrations at that distance from basin $\# 1$. If the plume axis lies either north or south of well H4-4, then the concentrations of contaminants at well H4-4 are assumed to be smaller than the peak concentrations along the true axis. It can be shown that if well H4-4 is assumed to lie on the plume axis, and if the triangular concentration distribution holds, the calculated net contaminant flux for any given flow rate is smaller than the net flux calculated for plume axes that lie either north or south of well H4-4. That is, by assuming a plume axis that passes through well H4-4, estimates of mass transport of contaminants to the Columbia River are conservatively low.

Figure 7 also illustrates stratigraphy for a section through wells $\mathrm{H4-4}$, $\mathrm{H} 4-11, \mathrm{H} 4-12 \mathrm{~A}, \mathrm{H} 4-12 \mathrm{~B}$, and H4-12C. The unconsolidated sands and gravels of the Hanford formation overlie the silty sands and gravelly silty sands of the Ringold Formation. According to Liikala et al. (1988), the Ringold Formation is generally less transmissive, and hydraulic communication at the interface between the two formations in the $100-\mathrm{H}$ Area is poor. Further, analytical data for samples collected from well $\mathrm{H} 4-12 \mathrm{C}$, which is completed within the Ringold Formation, show no evidence of contamination by the basin plume. Therefore, it is assumed that the basin plume is entirely within the saturated thickness of the Hanford formation. For the section shown in Figure 7 , the average saturated thickness is $4.3 \mathrm{~m}$. 


\section{Distance in Meters}
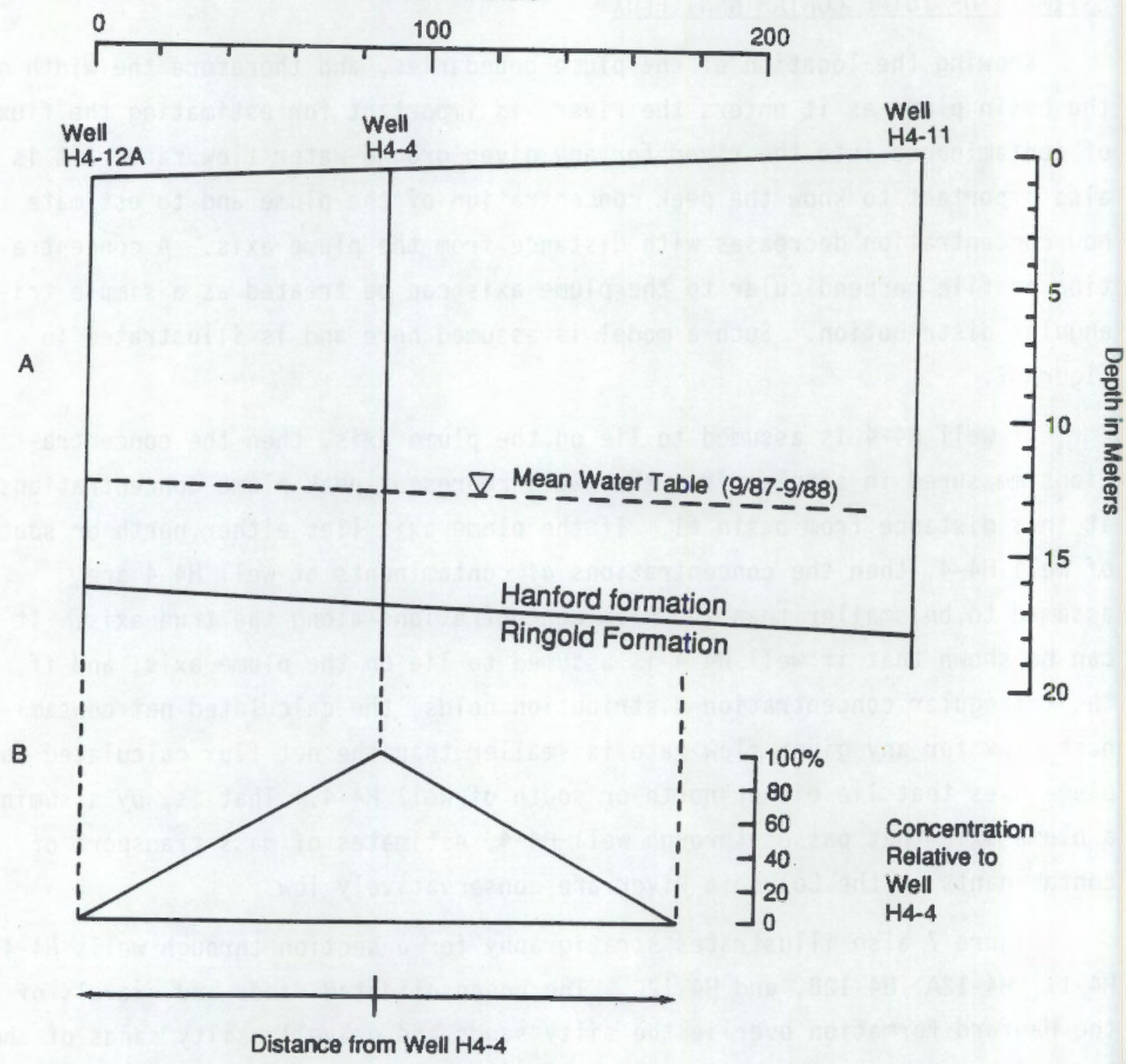

FIGURE 7. Concentration Profile Across the Width of the Contaminant Plume Near the Columbia River (A shows stratigraphy and mean water table near the Columbia River. B represents the simple triangular concentration profile across the width of the contaminant plume.)

Nitrate data are used here to provide an estimate of the total amount of liquid waste that leaked from basin $\# 1$ and reached the water table. It is assumed that the ground-water flow rate (taken here as $55 \mathrm{~cm} / \mathrm{d}$ ) and background nitrate concentration $(19 \mathrm{mg} / \mathrm{L})$ have not significantly changed since basin \#l started to leak, that the effective porosity for the Hanford formation is $20 \%$, and that the basin plume is symmetrical about its axis. 
Nitrate data for well H4-4 are only available from mid-1985 (when the well was constructed) to the present. However, it is possible to estimate what the nitrate concentrations would have been at the location of well H4-4 prior to mid-1985 by comparing available well $\mathrm{H} 4-4$ data to corresponding well H4-3 data (8 months earlier to allow for the necessary travel time of $55 \mathrm{~cm} / \mathrm{d}$ ) and then calculating a correction factor to apply to early well $\mathrm{H4-3}$ data. Such calculations, done on a mean annual basis, are sumnarized in Table 3. The result is a correction factor equal to 0.24 .

The effective cross-sectional area of the plume through the well H4-4 location is equal to plume width times saturated aquifer thickness times effective porosity $(130 \mathrm{~m} \times 4.3 \mathrm{~m} \times .2)$, or $112 \mathrm{~m}^{2}$. At $55 \mathrm{~cm} / \mathrm{d}$ annual volume of flow is therefore $22,000,000 \mathrm{~L} / \mathrm{yr}$. For each year, the amount of nitrate transported (see Table 4) is calculated as volume times concentration times one-half (the factor of one-half accounts for the triangular concentration distribution assumed for the plume). Total nitrate transported since basin \#1 began to leak is estimated to be $47,000 \mathrm{~kg}$. This is equivalent to $214,000 \mathrm{~L}$ of the liquid fraction of the slurry samples collected from basin \#1, or about $13 \%$ of the capacity of the basin. Also, this represents about $3 \%$ of the total amount of nitrate added to the basin during its waste storage service life.

An estimate of total nitrate discharged to the river has also been made using data from well H4-3. However, the geologic logs for well H4-3, as provided by Liikala et al. (1988) are difficult to interpret for effective saturated thickness. Using data from wells H4-8, H4-9, and H4-18 to construct a fence diagram through the well H4-3 site, an effective saturated

TABLE 3. Correlation of Nitrate Concentrations of Wells H4-3 and H4-4, Assuming 8 Months Travel Time from Well H4-3 to well H4-4, and a $19 \mathrm{mg} / \mathrm{L}$ Background Concentration

\begin{tabular}{|c|c|c|c|c|c|c|}
\hline \multicolumn{3}{|c|}{$\mathrm{Well} \mathrm{H}_{4}-3$} & \multicolumn{3}{|c|}{ Well $\mathrm{H}_{4}-4$} & \\
\hline Period & $\begin{array}{c}\mathrm{A} \\
\text { Mean } \mathrm{NO}_{3} \\
(\mathrm{mg} / \mathrm{L})\end{array}$ & $\begin{array}{c}\text { B } \\
\text { A less } 19 \\
(\mathrm{mg} / \mathrm{L})\end{array}$ & Period & $\begin{array}{c}\mathrm{C} \\
\mathrm{Mean} \mathrm{NO}_{3} \\
(\mathrm{mq} / \mathrm{L})^{2}\end{array}$ & $\begin{array}{c}0 \\
\text { C 1ess } 19 \\
(\mathrm{mg} / \mathrm{L})\end{array}$ & $B: 0$ \\
\hline $\begin{array}{l}2 / 87-1 / 88 \\
2 / 86-1 / 87 \\
2 / 85-1 / 86 \\
\text { MEAN = }\end{array}$ & $\begin{array}{r}606 \\
1569 \\
1014\end{array}$ & $\begin{array}{r}587 \\
1550 \\
995\end{array}$ & $\begin{array}{l}10 / 87-9 / 88 \\
10 / 86-9 / 87 \\
10 / 85-9 / 86\end{array}$ & $\begin{array}{l}227 \\
350 \\
235\end{array}$ & $\begin{array}{l}208 \\
331 \\
216\end{array}$ & $\begin{array}{l}2.82: 1 \\
4.88: 1 \\
4.61: 1 \\
4.1: 1\end{array}$ \\
\hline
\end{tabular}


TABLE 4. Total Nitrate Flux from Bas in \#1, Based on Estimated Plume Dimensions at Well $\mathrm{H} 4-4$, Flow Rate, and Concentration Data from Well $\mathrm{H} 4-3$

\begin{tabular}{|c|c|c|c|c|}
\hline Period & Mean $\mathrm{NO}_{3}^{\mathrm{A}}(\mathrm{mg} / \mathrm{L})$ & A less $19 \mathrm{mg} / \mathrm{L}$ & $\begin{array}{c}C(\mathrm{a}) \\
B \div 4.1\end{array}$ & $\begin{array}{c}\mathrm{D}(\mathrm{b}) \\
\mathrm{kg} \mathrm{N} \mathrm{NO}_{3} \\
\text { transported }\end{array}$ \\
\hline $10 / 74-9 / 75$ & 34 & 15 & 4 & 44 \\
\hline $10 / 75-9 / 76$ & 157 & 138 & 34 & 374 \\
\hline $10 / 76-9 / 77$ & 1,976 & 1,957 & 477 & 5,247 \\
\hline $10 / 77-9 / 78$ & 3,900 & 3,881 & 947 & 10,417 \\
\hline $10 / 78-9 / 79$ & 2,738 & 2,719 & 663 & 7,293 \\
\hline $10 / 79-9 / 80$ & 1,457 & 1,438 & 351 & 3,861 \\
\hline $10 / 80-9 / 81$ & 901 & 882 & 215 & 2,365 \\
\hline $10 / 81-9 / 82$ & 942 & 923 & 225 & 2,475 \\
\hline $10 / 82-9 / 83$ & 1,368 & 1,349 & 329 & 3,619 \\
\hline $10 / 83-9 / 84$ & 778 & 759 & 185 & 2,035 \\
\hline $10 / 84-9 / 85$ & 749 & 730 & 178 & 1,958 \\
\hline $10 / 85-9 / 86$ & 1,813 & 1,794 & 438 & 4,818 \\
\hline $10 / 86-9 / 87$ & 615 & 596 & 145 & 1,595 \\
\hline $10 / 87-9 / 88$ & 347 & 328 & 80 & 880 \\
\hline Total nitrate & transported & & & $46,981 \mathrm{~kg}$ \\
\hline
\end{tabular}

(a) Nitrate concentrations for we11 H4-3 corrected to an effective concentration at we11 $\mathrm{H} 4-4$.

(b) Calculated using the formula:

$$
D=C \times\left(22 \times 10^{6} \mathrm{~L} / \mathrm{yr}\right) \times\left(10^{-6} \mathrm{~kg} / \mathrm{mg}\right) \times \frac{1}{2}
$$

thickness of about $1.3 \mathrm{~m}$ for the Hanford formation was established. Using nitrate data from well $\mathrm{H} 4-3$ (less the background of $19 \mathrm{mg} / \mathrm{L}$ ), a plume width of $96 \mathrm{~m}$ through the well $\mathrm{H} 4-3$ site, and other factors stated above, a similar figure $(44,000 \mathrm{~kg})$ for the total nitrate transported is obtained.

At a flow rate of 49 to $64 \mathrm{~cm} / \mathrm{d}$, ground-water flux has replaced the volume of ground water contained in the basin plume and transported it to the river about 10 to 13 times since 1977 . Therefore, most of the liquid waste that reached the water table has already been transported to the river. 


\section{DISCUSSION}

Much of the foregoing analysis is dependent on the assumption that the liquid fraction of the slurry samples collected from basin \#1 in October 1984 is representative of the waste that leaked from the basin to reach the water table. In Figure 8, the mean composition of the basin samples is compared to the mean composition of ground-water samples collected from well H4-3 from July 1987 to September 1988 for several constituents (this time period was chosen to correspond with the data shown in Figure 3). Ground-water concentrations were multiplied by a scaling factor of 511 to correct for the dilution of the waste liquid by ground water. That factor was determined by dividing basin liquid concentrations of sodium, nitrate, sulfate, and chromium in basin \#1 (Table 1) by the respective mean ground-water concentrations (less background concentrations) observed during that period of time, and by averaging the results. Except for uranium, which shows anomalously low concentrations in the ground water, the comparison provides convincing evidence that the basin samples do, in fact, reflect the source of the groundwater contamination.

The uranium anomaly can also be seen in Figure 4 . The solid circle in the figure represents the composition of the basin \#1 slurry liquid. Its position in the trilinear diagram, which is much nearer the uranium vertex than is area $\underline{a}$, indicates that ground-water samples from wells affected by the basin plume are deficient in uranium relative to the basin contents. It is possible that uranium was removed by sorption as the liquid percolated through the sediments underlying the basins. If this explanation for the uranium anomaly is correct, simple calculations show that roughly $90 \%$ of the uranium would have been stripped from the wastes somewhere between the basin leak and wel1 $\mathrm{H} 4-3$. That is, about $130 \mathrm{~kg}$ of uranium, from the $214,000 \mathrm{~L}$ of waste liquid that reached the water table, may have been retained in the sediments beneath the basin.

An alternate explanation is that some of the uranium from the solids dissolved or redissolved during the 6 years that elapsed from the time of 


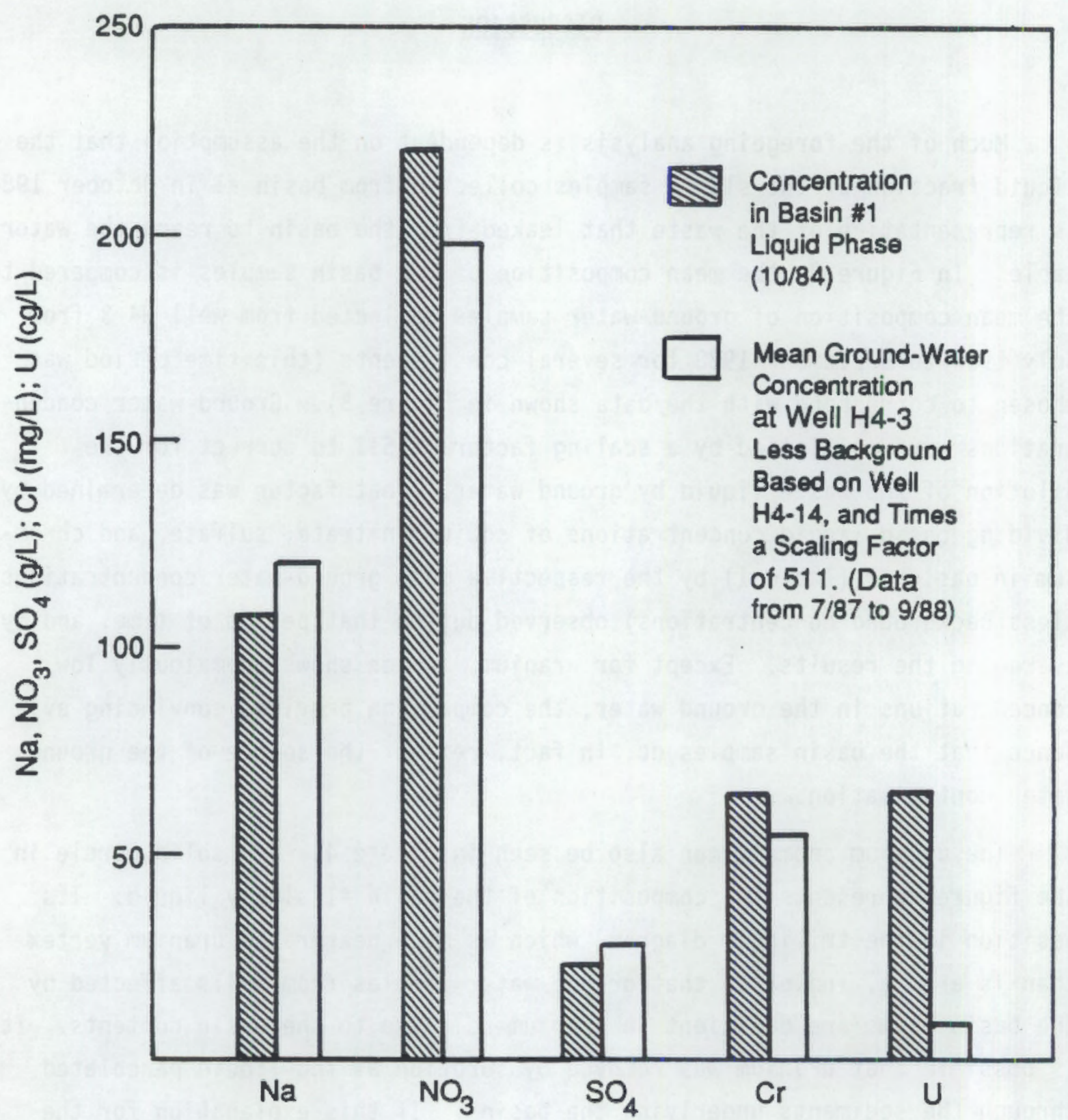

FIGURE 8. Composition of Basin \#1 Liquid Compared to the Composition of the Ground-Water Contaminant Plume

removal of the supernatant liquid to the time of slurry sampling. This process would have enriched the liquid of the slurry relative to the liquid that actually escaped from the basin. Originally, the acid waste from fuel processing (principally nitric acid) was over-neutralized with sodium hydroxide prior to being discharged to the basin. This over-neutralization may 
have caused precipitation of a solid uranium oxide phase. The alkaline liquid would act as a sink for atmospheric carbon dioxide, and over time the resulting carbonate solution would tend to redissoive the uranium as the highly soluble carbonate complex. Table 1 shows that the liquid waste samples collected in October 1984 are rich in carbonate species. However, it is impossible to know how much carbon dioxide absorption and consequent dissolution of any solid uranium phase occurred after, rather than before, basin \#1 leaked.

Note that in Figure 4 the lateral spread of area a along the technetium-99 - uranium axis is noticeable, but not extreme. That is, in ali of the samples from wells $\mathrm{H} 4-3$ and $\mathrm{H} 4-4$, the relative concentrations of technetium- 99 and uranium remained about the same. Present as the pertechnetate anion, technetium-99 is presumed to be conservative and mobile in the ground-water regime at the $100-\mathrm{H}$ Area. The highest uranium concentration represented in area $\underline{a}$ is $237 \mathrm{~kg} / \mathrm{L}$. Therefore, up to at least that concentration, it must be assumed that uranium is conservative in this particular aqueous geochemical environment, regardless of the possibility of nonconservative behavior at higher concentrations.

Depth to water table beneath the basins is approximately $11 \mathrm{~m}$. The waste liquid that reached the water table traversed this vertical span, but not all of the liquid that escaped the bas in would have reached the water table. Some fraction of the liquid that passed downward through the sediments would have been retained by capillarity. The amount of contamination "stored" within the unsaturated sediments would depend on the specific retention of the sediments and the volume of sediment contacted. The nitrate pulse detected in well H4-3 near the beginning of 1986 appears to represent the remobilization of part of this residual contamination.

The volume of sediments contacted by waste liquid beneath the basin depends on whether the flow path of the waste liquid as it moved downward was channeled or diffuse. In a planned drilling program, the vadose zone beneath the basins will be sampled to determine the total extent of contaminated sediments as well as the concentrations of contaminants.

The presence of contamination in well $\mathrm{H} 4-\mathrm{g}$ (Figure 2) and the location of that well suggest a spreading or diffuse flow path through the vadose 
zone. In a worst-case (or nearly so) analysis, it is possible to envision a flow path that passes downward from the approximate center of basin \#1 and that spreads in all directions just enough to involve well H4-9. The volume of sediment intercepted by this flow path is roughiy described by a cone extending from the basin to the water table. Assuming a specific retention of perhaps 5 to $7 \%$ for the sediments, simple calculations show that the volume of liquid waste retained in the soil column would be comparable to the estimated total volume that has al ready reached the water table.

Table 1 includes concentrations of copper, nickel, and fluoride found in basin \#1, and Table 2 includes concentrations of these elements in ground water samples collected from well H4-3. By applying the same scaling factor used in Figure 8 to the concentrations of these elements in well H4-3, it is seen that the combination of vadose zone and aquifer transport from the bas in to well H4-3 has resulted in attenuation of about $97 \%$ of the copper, $30 \%$ of the nickel (only present in the basin in trace quantities), and $90 \%$ of the fluoride. 


\section{CONCLUSIONS}

The contaminant plume extending from basin \#1 to the Columbia River has been superimposed upon a larger, pre-existing plume of like contaminants. By considering characteristic contaminant ratios in the liquid waste that escaped from basin $\frac{H}{\|}$, it has been possible to separate the relative contributions to chromium contamination of each of these sources, and to assign reasonable boundaries to the basin plume. A pulse of nitrate contamination has been used to estimate a net flow rate of 49 to $64 \mathrm{~cm} / \mathrm{d}$.

Nitrate data, along with estimated plume dimensions have possibly shown that the equivalent of $200,000 \mathrm{~L}$ of liquid waste from basin $\# 1$ reached the water table and was Jargely flushed to the river. A worst-case analysis for vadose zone transport of the liquid waste from the basin to the water table shows that a comparable volume of waste may have been retained in the soil column. A nitrate pulse detected in early 1986 appears to confirm that much of the contamination remaining on the soil column is soluble and potentially mobile. 
.

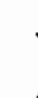

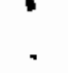




\section{REFERENCES}

Fruland, R. M., D. J. Bates, and R. E. Lundgren, eds. 1989a. Resource Conservation and Recovery Act Ground-Water Monitoring Projects for Hanford. Facilities: Progress Report for the Period July 1 to September $30,1988$. PNL-6789, Pacific Northwest Laboratory, Richland, Washington.

Fruland, R. M., D. J. Bates, and R. E. Lundgren, eds. 1989b. Resource Conservation and Recovery Act Ground-Water Monitoring Projects for Hanford Facilities: Progress Report for the Period October 1 to December $31,1988$. PNL-6844, Pacific Northwest Laboratory, Richland, Washington.

Fruland, R. M., and R. E. Lundgren, eds. 1989. RCRA Ground-Water Monitoring Projects for Hanford Facilities: Annual Progress Report for 1988. PNL-6852, Pacific Northwest Laboratory, Richland, Washington.

Greager, E. M. 1982. Environmental Effects of the Leakage From the 183-H Solar Evaporation Basins. UNI-2128, UNC Nuclear Industries, Richland, Washington.

Liikala, T. L., R. L. Aaberg, N. J. Aimo, D. J. Bates, T. J. Gilmore, E. J. Jensen, G. V. Last, P. L. Oberlander, K. B. Olsen, K. R. Oster, L. R. Roome, J. C. Simpson, S. S. Teel, and E. J. Westergard. 1988. Geohydrologic Characterization of the Area Surrounding the $183-\mathrm{H}$ Solar Evaporation Basins. PNL-6728, Pacific Northwest Laboratory, Richland, Washington.

PNL. 1987a. Ground-Water Monitoring Compliance Projects for Hanford Site Facilities: Progress Report for the Period July 1 to September 30, 1987. PNL-6469, Pacific Northwest Laboratory, Richland, Washington.

PNL. 1987b. Ground-Water Monitoring Compliance Projects for Hanford Site Facilities: Progress Report for the Period October 1 to December 31, 1987. PNL-6536, Pacific Northwest Laboratory, Richland, Washington.

PNL. 1988a. Ground-Water Monitoring Compliance Projects for Hanford Site Facilities: Progress Report for the Period January I to March 31, 1988. PNL-6581, Pacific Northwest Laboratory, Richland, Washington.

PNL. 1988b. Ground-Water Monitoring Compliance Projects for Hanford Site Facilities: Progress Report for the Period April I to June 30, 1988. PNL-6675, Pacific Northwest Laboratory, Richland, Washington.

Stenner, R. D., K. H. Cramer, K. A. Higiey, S. J. Jette, D. A. Lamar, T. J. McLaughl in, D. R. Sherwood, and N. C. Van Houten. 1988. Hazard Ranking System Evaluation of CERCLA Inactive Waste 5 ites at Hanford. PNL-6456, Pacific Northwest Laboratory, Richland, Washington. 
. 
PNL-7130

UC -903

\section{DISTRIBUTION}

No. of

Copies

OFFSITE

2 DOE/Office of Scientific and Technical Information

\section{ONSITE}

4 DOE Richland Operations office
E. A. Bracken
J. J. Broderick
K. M. Thompson
M. W. Tiernan

No. of

Copies

23 Pacific Northwest Laboratory

R. W. Bryce

J. W. Falco

H. R. Gorst

J. M. Hales

S. H. Halt (6)

P. C. Hays

T. L. Liikala

R. E. Lundgren

R. J. Serne

R. L. Skaggs

R. M. Smith

R. E. Wildung

Publishing Coordination

Technical Report Files (5)

5 Westinghouse Hanford Company
K. R. Fecht
B. H. Ford
V. G. Johnson
D. G. Kachele
R. E. Peterson 


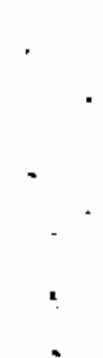
. 